\title{
The Effectiveness of Using the Lexical Approach to Developing Ethiopian EFL Learners' Vocabulary Competence
}

\author{
La efectividad del uso del Enfoque Léxico para desarrollar \\ la competencia de vocabulario en estudiantes etíopes de inglés \\ como lengua extranjera
}

\section{Addisu Sewbihon-Getie ${ }^{1}$}

\begin{abstract}
This study investigated the effects of teaching vocabulary through the lexical instructional approach in EFL intermediate level students. Ninety-five (95) students participated in a non-equivalent pre-test-post-test quasi-experimental design study. The participants were given vocabulary competence pre-test in order to check their homogeneity in terms of their vocabulary knowledge. Then, following the similitude of the results they scored, the participants were randomly assigned as experimental group and the control group. For sixteen (16) weeks, the experimental group was taught by providing students with chunks and/or collocates of words through using collocation dictionaries, concordance programs, chunk-for-chunk translation activities, and corpus-based activities etc. Whereas, the control group was taught the new words in isolation with conventional teaching techniques; for example, translation at single word level, synonyms, antonyms, and definitions. After the instructional intervention, both groups participated in a vocabulary competence post-test. The Statistical Package for Social Science (SPSS) software version 22 was employed to analyse the results. In this regard, an independent Samples T-test was run and the findings of the study showed that the experimental group outperformed the
\end{abstract}

He obtained his BA degree in Foreign Language and Literature in 2009 from Hawassa University, Ethiopia. Consecutively, he received his MA degree in TEFL in 2011 from Addis Ababa University, Ethiopia. He has taught English as a foreign language at Wolkite University, Ethiopia for several years. This paper is the result of his Ph.D. thesis which was sponsored by Wolkite University, his home institution.

sewbihonaddisu@yahoo.com

ORCID ID: https://orcid.org/0000-0002-7143-4282

Received: June 14th, 2020. Accepted: December 26th, 2020.

This article is licensed under a Creative Commons Attribution-Non-Commercial-No-Derivatives 4.0 International License. License Deed can be consulted at https://creativecommons.org/licenses/by-nc-nd/4.0. 
control group in the post-test which implies that teaching vocabulary with a lexically-based instruction can improve EFL learners' vocabulary competence or knowledge. Furthermore, the study results suggest that the lexical instructional approach should be the focus of future experimental research.

Keywords: collocation, lexical approach, lexical chunks, lexical instructional intervention, vocabulary competence

\section{Resumen}

Este estudio investigó los efectos de la enseñanza del vocabulario por medio del enfoque lexico instruccional en estudiantes de inglés como lengua extranjera de nivel intermedio. Noventa y cinco (95) estudiantes participaron en el estudio de diseño cuasi-experimental con pre- y post-test. A los participantes se les dio un pre-test de competencia de vocabulario con el fin de revisar la homogeneidad en su conocimiento sobre el mismo. Luego, siguiendo la similitud en los puntajes resultantes, a los participantes se les distribuyó aleatoriamente en un grupo de control y en otro experimental. Por dieciséis semanas, al grupo experimental se le enseñó con bloques y parejas de palabras usando diccionarios, programas equivalentes, y actividades de traducción de bloque a bloque y de corpus; mientras que al grupo de control se le enseñó las nuevas palabras por separado con técnicas de enseñanza convencionales, por ejemplo, traducción de cada palabra, sinónimos, antónimos y definiciones. Luego de la intervención instruccional, ambos grupos participaron en un post-test de competencia de vocabulario. Para analizar los resultados, se usó el software SPSS, versión 22. En este sentido, se usó también un T-test de muestra independiente cuyos resultados mostraron que el grupo experimental sobrepasó el grupo de control en el post-test, lo que implica que la enseñanza del vocabulario basada en el enfoque léxico puede mejorar la competencia o el conocimiento de vocabulario en los estudiantes de inglés como lengua extranjera. Es más, los resultados del estudio sugieren que el enfoque lexico instruccional debería ser el foco de futuras investigaciones experimentales sobre el tema.

Palabras clave: bloques léxicos, competencia en vocabulario, enfoque léxico, intervención léxico-instruccional, parejas léxicas

\section{Introduction}

The ever-growing need for good communication skills in English language has created a huge demand for teaching this language around the world. Millions of people today take different opportunities such as formal instruction, study abroad, media etc. to improve their command of English language. From these opportunities, the first one i.e. formal instruction is highly required to target an enormous demand for quality language teaching and language teaching materials (Richards, 2006). In relation to formal instruction, it is a known fact that there are different teaching approaches and methods which have been used to teach English language in different contexts and settings. Lexical approach is one of the communicative approaches that is being practiced these days. Theoretically, efforts were made to bring a paradigm shift on what traditionally claimed vocabulary and its teaching; for instance, language experts started recognizing the meaning-making potential of words 
and their importance for the second and foreign language learners (e.g. Singleton, 2000; McCarthy, O’Keeffe, \& Walsh, 2010). Different corpus-based evidences, which are the basis of lexical approach (Selivan, 2018), began to state the major role of vocabulary, later claimed to be lexis, in languages. Some innovative developments took place in lexicography which involved, as Carter (2001) puts it, "extensive corpora of spoken and written language and the creation of sophisticated computer-based access tools for such corpora" (p. 43) in the late 1980s and 1990s. Examples of such developments are the Collins Birmingham University International Language Database (COBUILD), Cambridge International Corpus, British National Corpus, etc.

The empirical data offered by these corpora studies enabled researchers to study the behaviour of words and expressions which in turn led them to question the traditional notions about the primacy of grammar in language and language pedagogy. This dominance of grammar and/or the relegation of words was highly opposed by Lewis (1993) who put forward his lexical approach--focusing on developing learners' lexical proficiency as an alternative to grammar-based approaches. Briefly speaking, the lexical approach, in second language acquisition, is an approach which concentrates on the role of lexis in English language learning rather than a primary focus on grammar (Lewis, 1993; Barcroft, 2004). It is an approach which considers the use of chunking and collocations at the centre of language teaching (Richards \& Rodgers, 2001; Scrivener, 2011). Thus, lexical approach can be summarized as a practically applicable methodology (Westfall \& Weber, 2005; Lewis, 2008), which places communication of meaning at the heart of language and language learning.

What is more, the Lexical Approach introduced a new paradigm for second language education, claiming that language consists of grammaticalized lexis, not lexicalised grammar (Lewis, 1993). More clearly, grammaticalized lexis refers to a word grammar approach in which the learner moves out from a word to discover its collocations and dominant grammatical patterns. For example, take this utterance: My mother holds very strong views on the subject of marriage. From this sentence target language learners notice that we can 'hold a view' that 'a view can be strong' and the word view is followed by the preposition 'on'. This leaves the learner with a chunk of a language: to hold very strong views on (something). Grammaticalized lexis which is sometimes referred as Word Grammar Approach tends to dissolve the strict dichotomy that we draw between grammar and vocabulary. Whereas, lexicalized grammar refers to the traditional 'slot and filler' approach in which prominent structures such as the tenses are highlighted. For example, in a typical lesson on the present perfect tense, the target language is presented with: I have been to ..., but I haven't been to ...yet. Here, the learner is encouraged to complete this frame with suitable vocabulary items. Example, I have been to America, but I haven't been to Italy yet. Thus, the lexicalized grammar, which is sometimes referred to as the slot-and-filler approach, enables the target language learner to produce huge amounts of grammatically well-formed language. 
Lexical Approach plays significant roles in improving EFL/ESL learners 'vocabulary competence. For clarification, Vocabulary/lexical competence is the ability to use words (i.e. their forms, meanings, and uses) in appropriate and effective ways in verbal interaction (Nation, 2001); it is a part of the communicative competence (Decarrico, 2001). According to Nation (2001), vocabulary competence directly shows the question of 'what does to know a word mean?' Therefore, lexical instruction is perhaps most compatible with communicative, task-based, text-based, and content-based approaches in which there is an emphasis on rich exposure to input (Timmis, 2008). Lexical Approach focuses on the concept 'lexis' to broaden the traditional notion of vocabulary, including under his (Lewis's) umbrella term both individual words and 'lexical chunks', i.e., groups of words that are commonly found together. To be brief, Lewis's notion, i.e. lexical approach in this paper, mainly includes: words and poly words, collocations, fixed expressions, and semi-fixed expressions.

Richards and Rodgers (2001) explain that Lexical Approach holds the belief that "the building blocks of language learning and communication are not grammar, functions, notions, or some other unit of planning and teaching but lexis, that is, words and word combinations" (p. 132). The immediate implication of Lewis's Lexical Approach for ELT is that teachers should help in the development of the learners' store of words and, especially, lexical chunks. Then, learners can retrieve these repertoire of chunks from their memory during language use. In other words, teachers should help in the development of learners' vocabulary/ lexical competence, which, among other things, includes the ability to use words and chunks in a variety of contexts in which their use is possible. Pedagogically, there are views about how teachers possibly do to enable target language learners develop their vocabulary/lexical competence. In this concern, there are three broad approaches to vocabulary teaching and learning. The first one is incidental learning, as Richards and Renandya (2002) put it, "learning vocabulary as a by-product of doing other things such as reading or listening skills" (p. 256). The second is an explicit teaching that is teachers teach directly by engaging learners in activities that centre round the development of vocabulary, and the third one is, teachers can develop learners' strategies that they would then be able to use independently for expanding their vocabulary bank.

There is a good psycholinguistic basis for believing that the mind stores, retains, and processes lexical chunks as individual wholes. The main reason stems from the structure of the mind itself; it can store vast amounts of lexical-chunks knowledge in long-term memory (Junying \& Xuefei, 2007). As far as literatures are concerned, EFL/ESL learners who are taught vocabulary through the lexical approach tend to develop their vocabulary competence and retain information in their long term-memory (e.g. Bircan, 2010; Lewis, 2008; Nation, 2001; Nation, 2005; Tremblay et al., 2011). Furthermore, learning in chunks is more effective than breaking into pieces (Lewis, 2008). Nation (2001), the advocate of collocations, confirms that there are three significant processes that may eventuate in remembering 
vocabulary: noticing, retrieval, and creative (generative) use. Noticing is paying attention to the vocabulary and being conscious of it. He generalizes that introducing different groupings (collocations) of new words can help students notice them and go through the first process to remember words. Teaching vocabulary through collocations enhances the expansion of vocabulary retention more than classical techniques such as definition, synonym, antonym, and mother tongue translation (Ghezelseflou \& Seyedrezaei, 2015).

Lexical chunks were read more readily than similar groups of words that were not considered as lexical chunks; as well, sentences constituting lexical bundles had more odds of being accurately remembered compared with sentences without lexical bundles (Bircan, 2010; Tremblay et al., 2011). Provided that the notion of chunks has been established in theories of language and SLA, empirical research into the most effective ways of teaching formulaic sequences/chunks remains limited (Boers \& Lindstromberg, 2012). This is to mean that despite the fact that lexical chunks are recognized in second and foreign language contexts, an extensive research was not done as per their roles in language teaching. The researcher shares this idea in the case of Ethiopia, and that is why this research work is intended to be carried out.

Literatures show that if we study the role of a certain language instructional approach to know its effects on the teaching/learning process, we can at least take some modifications and/or changes in our EFL/ESL classrooms. Lexical approach and its impact on students' vocabulary knowledge has to be tested, is the intention of this study. These days, the emphasis given to the carrier of meaning that is vocabulary, later expanded to lexis, is becoming high since the natural way of acquiring language is stored and retained in words and multi-words (Lewis, 2008). However, different language experts state that vocabulary is not given sufficient emphasis in EFL/ESL classrooms. Lewis (1993) describes, "There have been changing trends-from grammar translation to direct method to the communicative approach- but none of these has emphasized the importance of learners' lexical competence over structural grammatical competence” (p. 115). Likewise, Meara (1980), for example, called vocabulary a neglected aspect of second and foreign language (L2/FL) learning. Yet in recent research in various types of ESL classes, Folse (2010) concluded that vocabulary is indeed still neglected by many teachers, as the amount of "explicit vocabulary focus in a week of classes he observed was surprisingly low" (p. 139). The current researcher shares these claims because deliberate attention is not being paid to teach vocabulary in Ethiopian EFL classrooms (Alemu, 1994, Atkins et al., 1996, Dessie, 1988, Jeylan, 1999, as cited in Hailu, 2007; Minda, 2003; Hailu, 2007; Ismael, 2007; Gebreegizabiher, 2016). As the findings of these local studies show, grade nine learners (i.e. intermediate level in this context) are not capable of comprehending and producing something to the expected level due to the deficiency of appropriate vocabulary knowledge. As the findings of the aforementioned local studies indicate, EFL learners at grade nine level do have lexical problems in their production 
and comprehension skills. Therefore, even though plenty of studies have been done in order to alleviate EFL learners' lack of vocabulary knowledge, none of these has investigated the impacts of lexical approach vis-à-vis a conventional approach on the referred group of learners' vocabulary/ lexical competence in Ethiopia. The current vocabulary teaching method (i.e. conventional approach in this context) mainly provides opportunities for the learners to focus on translating English as a Foreign Language vocabulary into Amharic language, in the context of this study, at word-for-word level, looking for synonyms and/ or antonyms for certain single words (i.e. words in isolation), and explaining the definitions of the given list of words taken from reading and listening texts. Therefore, grade nine EFL textbook presents vocabulary activities and exercises in a manner that EFL learners can employ the referred strategies in their vocabulary learning. However, the conventional method has been found to ineffective, as the findings of local studies show. Thus, the researcher believes that lexical instructional approach can be a remedial mediation to teach vocabulary. In this regard, Willis (1990) makes an attempt to provide a rationale and design for lexically-based language teaching and suggests that a lexical syllabus should match an instructional methodology that puts particular emphasis on language use.

Unlike the lack of research works to the current researcher's context, there are studies conducted internationally, on the impact of lexical approach/lexical chunk instruction on the learners' writing, speaking, reading, and listening skills performances/proficiencies. For instance, recent studies have examined various topics regarding Lexical Approach. Researchers (e.g. Tang, 2012; Eidian et al., 2014; Chun-guang, 2014; Chao, 2016; Qader, 2016; Rahimkhani \& Hemmati, 2016; Abdulqader et al., 2017) showed in their studies that applying lexical approach or lexical chunks instruction in English language classrooms has positive effects on students' writing performance. Others (e.g. Attar \& Allami, 2013; Shooshtari \& Karami, 2013; Tuan \& Nguyen, 2014; Zafarghandi et al., 2015) found that the application of lexical approach / lexical chunk instruction has significant effects on students' speaking skills proficiency or performance.

Likewise, it is indicated that lexical collocation instruction has positive effects on learners' reading comprehension (e.g. Sahragard \& Sadighi, 2013). Tang (2013) did an experimental study and found out that acquisition of chunks can effectively help L2 learners to improve their listening competency. Again, Xu et al. (2012) and Rahimi and Momeni (2012) found out that using lexical approach and collocations (respectively) have positive effects on learners' English language proficiency in general. Some investigators found out that lexical collocation instruction has significant effects on learners' vocabulary learning and retention without difficulty (e.g. Seyedrezaei \& Ghezelseflou, 2015; Reza \& Ashouri, 2016). To be evident enough, the researcher conducted a preliminary study on grade nine EFL student textbook evaluation at Fasilo General Secondary and Higher Education Preparatory School found in Bahir Dar City, Amhara Region, Ethiopia. He collected data from the textbook by using 
document analysis and EFL teachers through interview. He found out that the vocabulary contents were not treated lexically in the textbook, and the EFL teachers did not have the awareness of teaching English language lexically. Therefore, the preliminary study findings confirm that there are no opportunities for learners to get the appropriate lexical input from the textbook as well as the teachers. This in turn surely leads the students to lack considerable vocabulary knowledge. Following those leading research findings, the researcher proposes his research problem. Therefore, this study intends to investigate whether or not lexical approach has significant effects on EFL learners' vocabulary competences.

Concerning rationales, to the best of the researcher's knowledge, there is no research work conducted on lexical approach in Ethiopia, and it is the first reason why the investigator become enthusiastic to instigate his study on it. The second reason that inspires the researcher to do his work in this area is because of different research findings that previous international researchers found so that the issue is unsettled. The third reason that made the researcher focus his work on this topic is the scholarly suggestions which come from known vocabulary expert, Nation (2001). He added that:

From a vocabulary learning point of view, we need research into collocation to tell us what the high frequency collocations are, to tell us what the unpredictable collocations of high frequency words are, to tell us what the common patterns of collocations are where some examples of that pattern would need special attention but where others could be predicted on the basis of this previous attention, and to provide dictionaries or information for dictionaries that help learners deal with low frequency collocations. (Nation, 2001, p. 529)

Thus, even if the Lexical Approach plays a part in enhancing target language learners' vocabulary acquisition, it is not known and investigated yet in Ethiopia, and the researcher would like to see if teaching vocabulary for EFL learners through this approach affects their vocabulary competences or knowledge. Therefore, this study attempted to answer the following research question:

RQ: Is there any significant difference between the vocabulary competence of the students who are instructed through the lexical approach and those who are instructed through the conventional approach?

\section{Review of Related Literature}

During the 1990s, there was an increased interest in vocabulary teaching and learning. Vocabulary teaching aspects like meanings, uses, and forms (spoken and written) were considered (Nation, 1991, 2001). At the same time, the advent of corpus linguistics and the COBUILD project of John Sinclair (1987) gave new impetus to theories on language acquisition. The studies then put forward a theory that is almost contrary to Chomskyan 
theory of language that holds the view that native speakers have a capacity of creating and interpreting unique sentences which they have never heard or produced previously. Moreover, Chomskyan theory believes that, "Linguistic competence consists solely in the ability to deploy an innate rule- governed sentence-making capacity" (Thornbury, 1998, p. 8). However, with the advent of corpus-based analyses, many linguists departed from the Chomskyan view to uphold the new theory of language, i.e. lexically-based instruction. According to Lewis (1993), the lexical instructional approach focusses on developing learner's proficiency with lexis, or word and word combinations. The Lexical Approach as a way of teaching language is devised by Lewis who views that language consists not of traditional grammar and vocabulary but often of multi-word prefabricated chunks. His idea is that an important part of language acquisition is the ability to comprehend and produce lexical phrases in such unanalysed 'wholes' - chunks (any pairs or groups of words which are commonly found together or in close proximity).

If the Lexical Approach is all about lexical chunks and/or collocations, it is better to elaborate the meanings of those concepts. Many attempts have been made to define lexical chunks. A chunk is "... a unit of memory organisation, formed by bringing together a set of already formed chunks in memory and welding them together into a larger unit" (Newall, 1990, pp. 124-125). Becker (1975) defines lexical chunks as a particular multiword phenomenon that is presented in the form of formulaic fixed and semi-fixed chunks. Nattinger and DeCarrico (1992) describe them as chunks of language of varying length and each chunk has a special discourse function. Biber et al. (1999) define them as "recurrent expressions regardless of their idiomaticity and regardless of their structural status" (p. 990). Yet again, Wray (2000, p. 465) added a mental explanation to the definition saying that, "a lexical chunk is a sequence of prefabricated words that are stored and retrieved as a whole from memory at the time of use." It is possible to put and generalize all these definitions as lexical chunks are a group of word combinations that frequently occur in a language with special meaning and function. As to Lewis, language is first about meaning, and meaning is primarily connected with the lexis. His term - lexical chunk - covers all the other terms connected with parts of language: words, collocations, fixed expressions, prefabricated phrases, and multi-word phrases. Lewis's theory follows from the language research that was based on the large computer-based corpora (collections of natural written and spoken text).

\section{The Role of the Lexical Approach/Lexical Chunks to Developing Learners' Vocabulary Competence}

Different scholars state that the lexical approach plays significant roles in enhancing the vocabulary capacity of EFL learners in different contexts. For instance, Schmitt (2004) has maintained the idea that lexical patterning affects the use of most words in discourse. This involves that language ability includes both the ability to produce fluent language 
syntactically and the ability to generate lexical chunks such as multiword units. One of the most compelling research-driven evidence on vocabulary learning has been provided by lexically-based language teaching (Willis \& Willis, 1989, Sinclair, 1991, as cited in Rahimi et al., 2012). Furthermore, Nation (2001) asserts that collocation has a lexical pattern. He claims that knowledge of collocation helps contextual vocabulary knowledge. In this regard, chunking words is one of the strategies that are often useful when putting large amounts of information into memory; by grouping disparate individual elements into larger blocks, information becomes easier to retain and memorize (Thornbury, 2002). Chunking is obvious in recall tasks, one can anticipate a higher proportion of correct recalls. Cognitive psychology claims that vocabulary knowledge is retained in a mental lexicon (Carroll, 2000; Aitchison, 2003).

Aitchison (2003) emphasizes that the large vocabulary size and efficiency of retrieval suggest that these words are carefully organized, not just stacked in random heaps, in the nature of a human word-store, or mental lexicon. The long-term stored mental lexicon, much like a paper dictionary, contains language information such as spelling, phonemes, meanings, and syntax. Even though it is rational to a certain extent that grammatical knowledge allows for the creative recombination of lexis in novel and imaginative ways, it cannot function in its role until learners have accumulated a sufficiently large mental lexicon (Lewis, 2000). It is vital to make students aware of chunks, giving the opportunities to recognize, organize, and record words in chunks. Recognizing chunks requires follow up, especially, for beginners and intermediate levels; they demand a lot of help and guidance. EFL teachers should play the important role in accelerating chunk noticing to occur. Noticing characteristics of the input, particularly the nature of the component chunks of the text has a facilitative value.

\section{The Needs to Chunking}

The concept of chunking has played a major theoretical role in cognitive psychology (Miller, 1956). This scholar introduced the concept of 'chunking' in his paper entitled 'The magical number seven, plus or minus two.' Chunking refers to a strategy for making more efficient use of short-term memory by breaking down large amounts of information into smaller chunks. Chase and Simon (1973, as cited in Moeller et al., 2009) suggested that the capacity of short-term (working) memory is limited to seven items, or chunks that is the formula $7 \pm 2$. Yet, chunking had been used to model a wide variety of memory phenomena (memory organization); however, in recent years, chunking has also been proposed as the basis for a model of human practice (Newell \& Rosenbloom, 1981; Rosenbloom \& Newell, 1987).

Mainly, Newell and Rosenbloom (1981) changed this concept into a model of practice by describing how performance could be improved by the acquisition of chunks that 
represent patterns of objects in the task environment. Even though it is believed that shortterm memory is limited to seven items only, the notion of vocabulary items or chunk varies. According to Moeller et al. (2009), chunking can mean both the breaking down of large amounts of information as well as grouping small chunks into larger categories. The main reason for the need of chunking vocabulary items is that the ability to break large language chunks into smaller ones, and to group small chunks into larger ones extends the process of retention of information and allows for greater compression of information in working memory (Kalivoda, 1981).

\section{Major Approaches for Chunking}

There are three major approaches to help learners chunk known components of words and word combinations (Nation, 2001), including: chunking through fuency development, chunking through language focused attention, and memorizing unanalysed chunks. To explain each briefly, the first and most important strategy is to help students develop the skills and knowledge that make it more efficient for them to chunk language items in larger units. It is likely that this fluency development is to some degree skill-specific so that learners would need to have fluency practice in listening, speaking, reading, and writing. Schmidt (1992) presents a comprehensive survey of a wide range of theories that can be used to explaining fluency development. The most accessible theory that describes the development of chunking through fluency development is McLaughlin's (1990) restructuring theory. The second major approach to help learners to chunk is through deliberate language focused attention. This attention can involve practice in chunking text containing familiar items, and the deliberate teaching and learning of collocates of known items. This can include "the use of concordances, matching activities, and the development of collocation tables" (Nation, 2001 p. 542). The third one that Nation (2001) indicates is memorization of unanalysed chunks which is an important learning strategy. This strategy can be applied to both regularly formed and irregularly formed chunks.

\section{Method}

\section{Research Design}

The researcher used a quasi-experimental design. Creswell (2009) shows that we use such a design when participants cannot be randomly selected or randomly assigned to groups (either control or treatment group). As literatures indicate, those designs are used when it is not possible to control all potentially confounding variables. Besides this, he believes that it is not possible to measure all the variables by using true experimental design so that quasiexperimental design is an alternative one instead. The researcher intends to employ a non- 
equivalent (Pre-Test and Post-Test) Control-Group Design. Both groups take a pre-test and post-test. Only the experimental group receives the treatment.

\section{Context and Participants of the Study}

The study was carried out at Fasilo General Secondary and Higher Education Preparatory School, grade nine, found in Bahir Dar City, Amhara Region, Ethiopia. The participants in this study were 95 (i.e. 48 students in section $\mathrm{H}$ and 47 students in section F) Amharic native speakers learning English as a foreign language at intermediate level. There were 27 female students in the former section and 25 female students in the latter section. Their ages range from 15 to 21 years old. There are 16 sections of grade nine students at this school, and the researcher selected two sections by using simple random sampling technique.

\section{Data Gathering Instrument}

\section{Tests}

In order to gather the quantitative data, the researcher employed pre-tests and post-test as explained below.

Pre-tests. The intent of the pre-tests were to know whether the participants of the study in the two sections have equal lexical competences or vocabulary knowledge. Because it was essential to inspect the homogeneity of the two sections prior to randomly assigning them as experimental and control groups, vocabulary competence tests at intermediate level were undertaken. To do so, the researcher adapted the concepts in order to design the tests. The sources from which he adapted concepts for the tests are: Intermediate Collocational Test designed by Cambridge University, Oxford Collocations Dictionary: for Students of English (2003). The pre-tests consist of three parts: 18 multiple choice items, 6 matching items, and 6 filling the blank spaces items that totally comprised 30 items on lexical chunks. The value weighted for each item in each part of the test was equal. The contents of the tests were taken from the ninth graders textbook which is being used regularly in the EFL classrooms. The time allotted for the participant to complete the test was an hour. The time given for them was determined in consultation with the EFL teachers who regularly teach at grade nine level.

Post-tests. After undertaking the intervention, both groups took post-tests (achievement tests) which were designed in a similar mode with the pre-tests. The intention of these tests was to examine if there were significant differences between the experimental group and the control group due to the delivery method provided (intervention). In addition to the sources from which the researcher adapted concepts, as done in the pre-tests, some criteria were also adopted and considered to prepare the post-tests. The following criteria were set out for identifying lexical chunks: modifiability versus non-modifiability, substitutability versus 
non-substitutability, compositionality versus non-compositionality (Lewis, 1993; Manning \& Schutze, 1999), and function versus form (Nattinger \& DeCarrico, 1992). Furthermore, by adapting procedures from the works of Garces et al. (2012), Rahimi et al. (2012), HyunJeong (2013), Yu (2013), Seyedrezaei and Ghezelseflou (2015), and Reza and Ashouri (2016), the researcher prepared the post-tests as well.

\section{Reliability and Validity of Data Gathering Instruments}

The researcher considered mechanisms to get the tools reliable and valid. Because there is no statistical test to determine whether a measure adequately covers a content area or adequately represents a construct, content validity usually depends on the judgment of experts in the field. Thus, the researcher consulted grade-nine EFL teachers, supervisors, and colleagues to check the validity and reliability of the tools, and received constructive comments. Besides this, the tests were pilot-tested.

\section{Preparation of Material for Intervention}

The researcher prepared the intervention material with the viewpoint of the Lexical Approach. The material prepared for the intervention reflected the pedagogical importance of chunks in an EFL/ESL classroom. According to Lewis (1993), pedagogical chunking should be a frequent classroom activity, as students need to gradually develop awareness of language to which they are exposed, "not only assembling parts into wholes, but also identifying constituent bits within the whole" (p. 195). The researcher adapted and incorporated different activities from Lewis (2008) such as intensive and extensive listening and reading in the target language; first and second language comparisons and translation-carried out chunkfor-chunk, rather than word-for-word-aimed at raising language awareness, and repetition and recycling of activities.

Besides this, the researcher focused on the activities about guessing the meaning of vocabulary items from context, noticing and recording language patterns and collocations, working with collocation dictionaries and other reference tools, and working with language corpuses created by the teacher for use in the classroom or accessible on the Internet, etc. while preparing the intervention material. The primary purpose of incorporating those activities in the teaching material was to raise students' awareness of lexical chunks, rather than teaching different ways of constructing sentences. The researcher depended on different sources to prepare the material as: The Lexical Approach: The State of ELT and a Way Forward by Lewis (1993), Teaching collocation: Further Developments in the Lexical Approach by Lewis (2000), Implementing the Lexical Approach: Putting Theory into Practice by Lewis (2008), Rules, Patterns and Words: Grammar and Lexis in English Language Teaching by Willis (2003), Oxford Collocations Dictionary: for Students of English (2003) etc.

HOW Journal 


\section{Intervention}

The intervention lasted for sixteen weeks. Concerning the number of hours per a week the intervention took place, one classroom session lasted for 43 minutes. That was the culture of the school for all subjects. Considering the natural process of the learning and teaching process of that school where the study was conducted, both the experimental and control groups had three English as a Foreign Language vocabulary classroom sessions independently (i.e. each session lasting for 43 minutes) in a week. That means, the intervention lasted for 129 minutes (i.e. 2.15 hours) per a week. The experimental group students were instructed by using the new teaching method (Lexical Instructional Approach) whereas the control group students were taught with the conventional method i.e. the usual teaching method. However, the input given for both groups was alike; for example, both group students were provided the same vocabulary contents but the mode of teaching was dissimilar. The intervention was carried out starting from October 14, 2019 - February 8, 2020. The time schedule was the same for both the experimental group and control groups. After the researcher gave him (the teacher experimenter) training, about the techniques how to implement the newly designed intervention material, the intervention went on. To avoid artificiality and bias, the researcher believed that the teacher experimenter was a best fit to conduct the intervention. To proceed the intervention, the teacher experimenter and the researcher prepared lesson plans. Unlike the PPP (Present-Practice-Produce) teaching methodology, which is being practiced in the conventional teaching method, the study followed the OHE (Observe-HypothesizeExperiment) teaching methodology.

Thus, the teacher experimenter was advised in the training to follow the OHE model which was devised by Lewis (1993). The diagram is designed by the researcher as shown below.

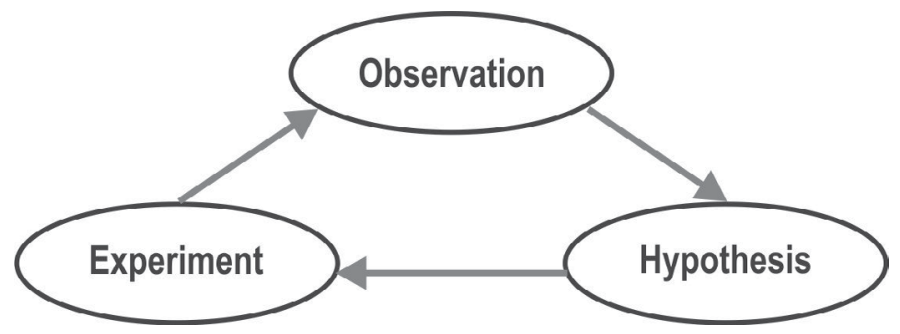

Figure 1. Intervention Framework: Observe-Hypothesize-Experiment Model (Lewis, 1993) 
To describe each of the phases, in the observation stage, students were presented with oral and written input. In the second phase, students compose a hypothesis about principles based on the perceived linguistic behaviour, and in the experiment phase, learners test their theories in a communicative context.

\section{Data Analysis Technique}

Data gathered through quantitative methods i.e. tests in this case, were analysed by using Statistical Package for Social Science (SPSS) software version 22. Thus, since this study includes one independent variable (Lexical Instructional Approach) with two groups and one dependent variable (vocabulary competence), an independent samples T-test was an appropriate method to run.

\section{Findings}

Following the data collection, the participants' vocabulary competence scores on the pre-tests and post-tests were measured. Prior to doing the main analysis of the results obtained from the tests, the assumptions of an independent-sample T-test were tested as noted in a research question part of this study, the question is: Is there a statistically significant difference between the vocabulary competence scores of the experimental group and the control group? Thus, to answer this question, it needs to test the assumptions before carrying out the detailed analysis. Checking the assumptions is a step forward in order to get valid and reliable results that make the whole study practical.

\section{Assumption Testing}

The assumptions of an independent samples T-test was tested before doing the analysis of the data obtained from the pre-test and the post test. Considering the remaining assumptions, which cannot be tested using SPSS, the normality of tests and homogeneity of variances were checked as presented below.

\section{Normality of Scores}

The Shapiro-Wilk test was used to check the assumption of normality of the vocabulary competence scores of students. The results are presented in Tables 1 and 2 below.

Considering the obtained Sig. values in Table 1 above, both of which are greater than 0.05 (i.e. $P>0.05$ ), the normality of the intended variable (pre-test) was supported at a significant level of 0.05 . Therefore, the assumption of test normality was met.

Considering the obtained Sig. values in Table 2 above, both the Shapiro-Wilk test results are greater than 0.05 . The normality of the post-test was supported at a significant level of 0.05 so that the assumption was met again. 
Table 1. Normality Test of Vocabulary Competence Pre-Test in Both Sections

\begin{tabular}{|l|l|c|c|c|c|c|c|}
\hline \multirow{2}{*}{} & \multirow{2}{*}{ Sections } & \multicolumn{3}{|c|}{ Kolmogorov-Smirnov } & \multicolumn{3}{|c|}{ Shapiro-Wilk } \\
\cline { 3 - 8 } & & Statistic & df & Sig. & Statistic & df & Sig. \\
\hline \multirow{2}{*}{$\begin{array}{l}\text { Vocabulary } \\
\text { competence pre-test }\end{array}$} & Section H & 0.106 & 48 & $0.200^{*}$ & 0.968 & 48 & 0.202 \\
\cline { 2 - 8 } & Section F & 0.124 & 47 & 0.067 & 0.962 & 47 & 0.130 \\
\hline
\end{tabular}

*. This is a lower bound of the true significance.

a. Lilliefors Significance Correction

Table 2. Normality Test of Vocabulary Competence Post-Test in Both Groups

\begin{tabular}{|l|l|c|c|c|c|c|c|}
\hline \multirow{2}{*}{ Groups } & \multicolumn{3}{|c|}{ Kolmogorov-Smirnov } & \multicolumn{3}{|c|}{ Shapiro-Wilk } \\
\cline { 3 - 9 } & Statistic & df & Sig. & Statistic & df & Sig. \\
\hline \multirow{2}{*}{$\begin{array}{l}\text { Vocabulary } \\
\text { competence } \\
\text { post-test }\end{array}$} & $\begin{array}{l}\text { Experimental } \\
\text { group students }\end{array}$ & 0.113 & 48 & 0.160 & 0.970 & 48 & 0.263 \\
\cline { 2 - 9 } & $\begin{array}{l}\text { Control group } \\
\text { students }\end{array}$ & 0.141 & 47 & 0.020 & 0.958 & 47 & 0.093 \\
\hline
\end{tabular}

a. Lilliefors Significance Correction

\section{Homogeneity of Variances}

Before randomly assigning the two section students into experimental and control groups so as to carry out the lexical instructional intervention, a pre-test was given for both. The purpose of giving pre-tests for both section students was in order to know whether students were homogenous in their lexical knowledge or not. The Tables 3 and 4 below show this.

Table 3. Descriptive Statistics of the Vocabulary Competence Pre-Test

\begin{tabular}{|l|l|c|c|c|c|}
\hline & Sections & N & Mean & $\begin{array}{c}\text { Std. } \\
\text { Deviation }\end{array}$ & $\begin{array}{c}\text { Std. Error } \\
\text { Mean }\end{array}$ \\
\hline \multirow{2}{*}{$\begin{array}{l}\text { Vocabulary Competence } \\
\text { pre-test }\end{array}$} & Section H & 48 & 11.71 & 2.333 & 0.337 \\
\cline { 2 - 6 } & Section F & 47 & 11.45 & 2.483 & 0.362 \\
\hline
\end{tabular}

As Table 3 in the above indicates, the scores of the two sections on the vocabulary competence test showed remarkable similarities. The results indicate that the mean score of 
section $H$ is $(M=11.71$ and $S D=2.333)$, whereas the mean score of section $F$ is $(M=11.45$ and $\mathrm{SD}=2.483$ ). Therefore, the two sections seemed to have mathematically similar achievement. However, an independent-sample T-test was run in order to make certain that the two sections did not differ significantly before they were exposed to the lexical instructional intervention. The Table below clearly shows this.

Table 4. Vocabulary Competence Pre-Test: Significance of Groups’ Mean Scores Difference

\begin{tabular}{|c|c|c|c|c|c|c|c|c|}
\hline & \multicolumn{7}{|c|}{ T-test for Equality of Means } \\
\hline & & \multirow[t]{2}{*}{$\mathbf{t}$} & \multirow[t]{2}{*}{ df } & \multirow[t]{2}{*}{$\begin{array}{c}\text { Sig. } \\
\text { (2-tailed) }\end{array}$} & \multirow[t]{2}{*}{$\begin{array}{c}\text { Mean } \\
\text { Difference }\end{array}$} & \multirow[t]{2}{*}{$\begin{array}{l}\text { Std. Error } \\
\text { Difference }\end{array}$} & \multicolumn{2}{|c|}{$\begin{array}{l}95 \% \text { Confidence } \\
\text { Interval of the } \\
\text { Difference }\end{array}$} \\
\hline & & & & & & & Lower & Upper \\
\hline $\begin{array}{l}\text { Vocabulary } \\
\text { Competence } \\
\text { pre-test }\end{array}$ & $\begin{array}{l}\text { Equal } \\
\text { variances } \\
\text { assumed }\end{array}$ & 0.529 & 93 & 0.598 & 0.262 & 0.494 & -0.720 & 1.243 \\
\hline
\end{tabular}

An independent-sample T-test was run to check the homogeneity of the two sections (section $\mathrm{H}$ and section $\mathrm{F}$ ) in their vocabulary competence before the intervention was carried out. As indicated in Table 4 above, $\mathrm{t}(93)=0.529, P>0.05$ which suggests that the two sections were homogeneous in terms of their vocabulary competence or knowledge. Therefore, the assumption of homogeneity of variance was met. Impliedly, since there was not significant difference between the two sections in terms of their vocabulary knowledge, it was possible to randomly assign them as experimental and control groups in order to conduct the instructional intervention.

\section{The Results of the Analyses of Vocabulary Competence Post-test}

After the experimental and control group students were exposed for the lexical instructional intervention, a post-test was given for them. Then, the exam papers were marked. The results obtained were analysed by using descriptive and inferential statistics. The Tables 5 and 6 below clearly show this again.

After the intervention, a 30-item vocabulary competence test was given as the posttest. As depicted in Table 5 above, the mean score and standard deviation for vocabulary competence post-test of the experimental group are 22.17 and 2.215 respectively whereas the control group scored the mean $(\mathrm{M}=20.81)$ and the standard deviation $(\mathrm{SD}=1.676)$. From these scores it is possible to say that there was a mathematical difference between 
experimental group and the control group. The difference might come about owing to the instructional intervention provided. Nevertheless, the independent samples T-test was run to make sure that a statistically significant difference occurred because of the mode of teaching (intervention). The table below shows this.

Table 5. Descriptive Statistics of the Vocabulary Competence Post-Test

\begin{tabular}{|l|l|c|c|c|c|}
\hline & \multicolumn{1}{|c|}{ Groups } & N & Mean & $\begin{array}{c}\text { Std. } \\
\text { Deviation }\end{array}$ & $\begin{array}{c}\text { Std. Error } \\
\text { Mean }\end{array}$ \\
\hline Vocabulary \\
Competence post-test & $\begin{array}{l}\text { Experimental } \\
\text { group students }\end{array}$ & 48 & 22.17 & 2.215 & .320 \\
\cline { 2 - 6 } & Control group students & 47 & 20.81 & 1.676 & .245 \\
\hline
\end{tabular}

Table 6. Vocabulary Competence Post-Test: Significance of Groups’ Mean Scores Difference

\begin{tabular}{|c|c|c|c|c|c|c|c|c|c|c|}
\hline & & \multicolumn{2}{|c|}{$\begin{array}{l}\text { Levene's Test } \\
\text { for Equality } \\
\text { of Variances }\end{array}$} & \multicolumn{7}{|c|}{ T-test for Equality of Means } \\
\hline & & \multirow[t]{2}{*}{ F } & \multirow[t]{2}{*}{ Sig. } & \multirow[t]{2}{*}{$\mathbf{t}$} & \multirow[t]{2}{*}{ df } & \multirow[t]{2}{*}{$\begin{array}{c}\text { Sig. } \\
\text { (2-tailed) }\end{array}$} & \multirow[t]{2}{*}{$\begin{array}{c}\text { Mean } \\
\text { Difference }\end{array}$} & \multirow[t]{2}{*}{$\begin{array}{l}\text { Std. Error } \\
\text { Difference }\end{array}$} & \multicolumn{2}{|c|}{$\begin{array}{l}95 \% \text { Confidence } \\
\text { Interval of } \\
\text { the Difference }\end{array}$} \\
\hline & & & & & & & & & Lower & Upper \\
\hline \multirow{2}{*}{$\begin{array}{l}\text { Vocabulary } \\
\text { Competence } \\
\text { post-test }\end{array}$} & $\begin{array}{l}\text { Equal } \\
\text { variances } \\
\text { assumed }\end{array}$ & 3.484 & 0.065 & 3.364 & 93 & 0.001 & 1.358 & 0.404 & 0.556 & 2.160 \\
\hline & $\begin{array}{l}\text { Equal } \\
\text { variances } \\
\text { not } \\
\text { assumed }\end{array}$ & & & 3.374 & 87.478 & 0.001 & 1.358 & 0.403 & 0.558 & 2.158 \\
\hline
\end{tabular}

As indicated in Table 6 above, an independent samples t-test was run again to see whether there was a statistically significant difference between the two groups of students in terms of their scores on the vocabulary competence post-test measured after the instructional intervention was carried out. In this regard, $\mathrm{t}(93)=3.364, P<0.05$ which indicates that the experimental group outperformed the control group in terms of the vocabulary competence post-test. That is to say, the former group's improvement was statistically significant with 
respect to vocabulary competence (i.e. $P=.001)$. Generally the question, "Is there a statistically significant difference between the vocabulary competence scores of the experimental group and the control group?" was answered in such a way that the lexical instructional approach had positive impacts on students' vocabulary competence. Therefore, the state of the arts (i.e. contemporary theories on teaching language lexically) which state that lexical instruction improves students' vocabulary knowledge was actually tested and had noticeable effects on their learning generally.

\section{The Aspects of the Lexical Knowledge that the Experimental Group Students Improved}

In the context of the present study, there were aspects of the lexical knowledge in which the experimental-group students improved after they were instructed through the lexicalapproach-based teaching. For example, students' abilities to combine words which can go together naturally were developed. Besides, the students were able to identify lexical chunks from the given authentic texts which were utilized during the intervention. After they were informed about how to identify the lexical items from texts, the experimental-group students became clear about looking for the nodes for a considerable number of collocates. Before they were doing activities based on texts, the students were given simple exercises; for instance, for the collocates like take a , re-take a fail a , pass a , get a good score on a __ etc., the students were requested to think and look for the node (i.e. the word "Test" in this context). Then, they developed their knowledge of chunking words as take a test, retake a test, fail a test, pass a test, get a good score on a test, etc. Accordingly, their knowledge of chunking/combining words, in which the students are not familiar with, found in the texts were improved. For instance, in a reading text entitled "Places to visit", students were requested to recognize the collocates of the word "recommended". By using collocation dictionaries uploaded in their mobiles, the students could chunk words like highly recommended, definitively recommend, personally recommended, heartily recommended, warmly recommended, to recommend, recommend something/somebody for___. In such a vein, the experimental-group students were able to chunk words they already knew and words in which they were not familiar with.

What is more, students' knowledge of homonymous words was developed. For instance, words like Kind (to mean type/caring), bark (to mean a tree's out layer/the sound a dog makes), address (to mean location/solve a problem), right (to mean correct/direction opposite of left) etc., were the examples in which the experimental-group students improved. In addition, the students developed their idiomatic expressions (fixed expressions in this context) like bread and butter (which mean the basic source of income), kick the bucket (to die), running cats and dogs etc. Generally, the students developed their collocational and/or lexical knowledge because of the mode of teaching. The main emphasis of the intervention was to get students to become aware about the strategies how to combine words that can 
co-occur naturally. They recognized the ways that can help them identify lexical items from texts. Then, the type of lexical items they have already identified and chunked was grouped under the category which includes words and poly-words, collocations, fixed expression, and semifixed expressions. All in all, whatever category a certain lexical item is put, the students recognized the structure and function of it as the criteria to use in their language learning. While doing the lexical chunk activities, the students understood and then developed the grammar patterns of words, too. Finally, students' word grammar, word usage, function etc. were found improved.

\section{Discussions}

The findings obtained in this study led to the conclusion that there was a statistically significant difference between the vocabulary competence mean score of the two groups allowing the researcher to reject the null hypothesis. The null hypothesis assumes that there is no significant difference between the mean score of the experimental group that was instructed with the lexical instructional approach and the control group that was instructed with the conventional approach. However, considering the findings, it was possible to say that the two groups had statistically significant differences in terms of the vocabulary improvement after the intervention. Hence, this study safeguards the effectiveness of the Lexical Instructional Approach activities in teaching vocabulary to EFL learners at intermediate levels i.e. in high schools. Likewise, the study advocates that implementing the Lexical Instructional Approach activities can help learners improve their knowledge of vocabulary or vocabulary competence. Concerning the process of the intervention and its ultimate impacts, there was sufficient time to appropriately do each and every activity, task, and exercise. The research findings indicated that since the students were requested to identify chunks from texts, group the words in accordance with their associations, look for the nodes for the collocates, look for the collocates for the nodes or key words, and apply the concordance programs to extract word patterning, they were more active and lively in class while they were learning the vocabulary contents. They undertook all these activities by themselves after they were given the examples, exercises, and tasks in their handouts. This implies that lexical instructional approach was also a better fit for an independent learning to take place.

This study is in congruent with studies by Tang (2012), Eidian et al. (2014), Chun-guang (2014), Chao (2016), Qader (2016), Rahimkhani and Hemmati (2016), and Abdulqader et al. (2017) who conducted their research works on the impacts of lexical approach and/ or lexical chunk instruction on students' writing performances, and they found out that this instructional approach had positive impacts on students' writing improvements. They suggested that this approach should be implemented in EFL/ESL contexts. Furthermore, the 
findings of the study are in line with the findings of Attar and Allami (2013), Shooshtari and Karami, (2013), Tuan and Nguyen (2014), and Zafarghandi et al. (2015) who concluded that lexical approach/lexical chunk instruction is effective in improving students' speaking skills proficiencies or performances. Likewise, the results of the present study give more support to the findings of many studies (e.g. Rahimi \& Momeni, 2012; Xu et al., 2012; Abdellah, 2015; Seyedrezaei \& Ghezelseflou, 2015; Ördem \& Paker, 2016; and Reza \& Ashouri, 2016) conducted on the effects of collocation and lexical chunk instruction on students vocabulary development. These researchers found that using collocations, in particular, and the Lexical Approach, in general, has positive effects on learners' English language vocabulary competence.

\section{Conclusions}

The current research work reveals the importance of the lexical instructional approach in teaching English as a Foreign Language vocabulary and to develop learners' vocabulary competence at the ninth-grade level. Therefore, EFL learners need to be exposed for high volume of input texts that contain frequently used and natural lexical chunks that can fit different situations in the whole teaching and learning process. From psycholinguistics point of view, learning words with chunks or in chunk forms could reduce the much amount of efforts that both teachers and learners have probably exerted (Lewis, 2008). As indicated in the literature review part of this study, more meanings are carried by words and word chunks rather than grammatical structures. Thus, it can be concluded that appropriate and deliberate attention should be paid for teaching vocabulary with chunk forms rather than single words (words in isolation) as is the case in the currently in-use method of the ninth-grade level. Hence, with regard to the findings of the current study, it can be concluded that teaching vocabulary through the Lexical Approach or lexical chunks instruction substantiates to be more valuable and suitable for the EFL learners than through the currently implemented method or conventional method at ninth-grade level. Besides, the newly implemented vocabulary teaching method, i.e. lexical instructional approach, has positive effects not only on vocabulary competence, but also on linguistic creativity at word level, motivation, and potential value of technology-mediation (i.e. student interaction with computer-based technology-intrapersonal interaction) in order to use concordance programs. It can also be concluded that Ethiopian EFL learners at high schools-intermediate levels are positively in need of a suitable, practical, and culturally-inspired lexical-based instruction to improve their vocabulary knowledge in particular and the English language proficiency in general.

\section{Recommendations}

Therefore, as far as the results of the current study imply, it is possible to make some recommendations. To begin with, the findings are congruent with other internationally 
conducted research works which are directly or indirectly in connection with vocabulary teaching through lexical approach. The indirectly connected researches were done on the impacts of lexical approach on learners' writing and speaking skills performances, and the findings indicate that this approach had positive effects on their performances in terms of the skills referred. The rest studies were directly connected to this study and the results show that this approach had good improvements on students' vocabulary knowledge, or competences in general. Therefore, all these findings could corroborate and strengthen the implications of the present study. From the researcher's context, he would like to kindly suggest that vocabulary learning should be a major concern in teaching EFL because theorists on Lexical Approach assert that the centre of language learning should be on word combinations or lexical chunks in general and the practices (the research findings obtained) could substantiate this, too. Theorists on lexical approach or lexical instruction argue that the lack of vocabulary knowledge or competence affects all other aspects or contents of EFL damagingly and unnaturally; thus, in order to alleviate this, the vocabulary activities, tasks and exercises should be designed in the context of Lexical Approach. In this regard, syllabus designers and the Ethiopian Ministry of Education, should give the appropriate status for Lexical Approach-based teaching in the syllabus and curriculum. Furthermore, it is implied that by incorporating lexically-based teaching as additional techniques, the EFL teachers should make their activities and tasks suitable and sufficient so as it is possible to complement the textbooks of EFL in intermediate levels. All over again, it is suggested that EFL teachers should make efforts to design and develop their own Lexical Approachgrounded activities that can suit their pupils' needs, cultures, norms, and educational levels rather than simply adopting the approach as it is. Finally, following the study results, lexicallybased teaching and its impacts should be the focus of future experimental research.

\section{Limitations}

Like any other research works, studies on language teaching and learning cannot be without limitations. This study does have limitations. The first limitation is that the duration of the intervention provided. As the study lasted for sixteen (16) weeks, the researcher admitted about the insufficient time. He claims that it needs, at least one year, to carry out the Lexical Instructional Approach intervention because this approach is somewhat a vast concept. The second limitation is based on the nature of sample size. The participants of this study were taken from only one high school which could not lead the study to represent all schools in the town. Thus, large sample of participants should have been considered for the study in order to obtain more factual data. The other limitation of the study was conducted on EFL leaners' vocabulary competence so that it could not inform the readers about the impact of the Lexical Approach on other language skills. 


\section{References}

Abdellah, A. S. (2015). The effect of a program based on the lexical approach on developing English majors' use of collocations. Journal of Language Teaching and Research, 6(4), 766-777.

Abdulqader, H. B., Murad, I. H., \& Abdulghani, M. I. (2017). The impact of the application of lexical approach on developing students' writing skills at a university level. European Scientific Journal, 13(32), 130-141. https://doi.org/10.19044/esj.2017.v13n32p130

Aitchison, J. (2003). Words in the Mind: An introduction to the mental lexicon. Blackwell.

Attar, E. M., \& Allami, H. (2013). The effects of teaching lexical collocations on speaking ability of Iranian EFL learners. Theory and Practice in Language Studies, 3(6), 1070.

Barcroft, J. (2004). Second language vocabulary acquisition: A lexical input processing approach. Foreign Language Annals, 37(2), 200-208.

Becker, J. (1975). The phrasal lexicon. In B. L. Nash-Webber \& R. Schank (Eds.), Theoretical issues in natural language processing (pp. 70-73). Bolt, Beranek \& Newman.

Biber, D., Johansson, S., Leech, G., Conrad, S., \& Finegan, E. (1999). Longman grammar of spoken and written English. Longman.

Bircan, P. (2010). Lexical Approach in teaching vocabulary to young language learners [Unpublished dissertation]. Andolu University.

Boers, F., \& Lindstromberg, S. (2012). Experimental and intervention studies on formulaic sequences in a second language. Annual Review of Applied Linguistics, 32, 83-110.

Carroll, D. W. (2000). Psychology of language ( $3^{\text {rd }}$ ed.). Foreign Language Teaching and Research Press.

Carter, R. (2001). Vocabulary. In R. Carter \& D. Nunan (Eds.), The Cambridge guide to teaching English to speakers of other languages (pp. 42-47). Cambridge University Press.

Chao, L. (2016). A lexical-chunk based study of business English correspondence writing. Sino-US English Teaching, 13(4), 277-283.

Chun-guang, T. (2014). An empirical research on the corpus-driven lexical chunks instruction. International Journal of English Language Teaching, 2(2), 1-36.

Creswell, J. W. (2009). Research design: Qualitative, quantitative, and mixed methods approaches (3 ${ }^{\text {rd }}$ ed.). Sage Publications.

Decarrico, J. S. (2001). Vocabulary learning and teaching. In M. Celce-Murcia (Ed.), Teaching English as a second or foreign language (pp. 285-289). Heinle \&Heinle.

Eidian, F., Gorjian, B., \& Aghvami, F. (2014). The impact of lexical collocation instruction on developing writing skill among Iranian EFL learners. International Journal of Language Learning and Applied Linguistics World, 4(3), 001-006.

Folse, K. S. (2010). Is explicit vocabulary focus the reading teacher's job? Reading in a Foreign Language, 22, 139-160.

Garces, J. A., Diaz, B. D., \& Judikis, D. O. (2012). The significance of vocabulary in language teaching: Groundbreaking research on the application of the lexical approach in Punta Arenas [Unpublished dissertation]. Universidad de Magallanes. 
Gebreezabhar, G. (2016). An evaluation of the design of vocabulary tasks and their implementation with reference to grade nine English textbook [Unpublished master dissertation]. Addis Ababa University.

Ghezelseflou, M., \& Seyedrezaei, S. H. (2015). The effect of teaching vocabulary through collocations on the vocabulary retention of Iranian EFL students. International Journal of Basic Sciences \& Applied Research, 4(3), 162-170.

Hailu, M. (2007). A study of vocabulary teaching techniques via plasma TV and students' attitude towards the techniques: A case of three government high schools in Addis Ababa with references to grade nine [Unpublished dissertation]. Addis Ababa University.

Hyun-Jeong, N. (2013). Implementing the lexical approach to teaching English grammar to Korean L2 learners. Modern Studies in English Language and Literature, 57(3), 324-347.

Ismael, A. (2007). Analysis of the effectiveness of contextual guessing activities: Grade 11 in focus [Unpublished master dissertation]. Addis Ababa University.

Junying, Z., \& Xuefei, W. (2007). Chunking- An effective approach to vocabulary teaching and learning in college classrooms. CELEA Journal, 30(3), 79-84.

Kalivoda, T. (1981). Developing advanced listening comprehension skill in a foreign language: Problems and possibilities. Hispania, 64(1), 80-85.

Lewis, M. (1993). The lexical approach: The state of ELT and a way forward. Language Teaching Publications.

Lewis, M. (2000). Teaching collocation: Further developments in the lexical approach. Language Teaching Publications.

Lewis, M. (2008). Implementing the lexical approach: Putting theory into practice. Language Teaching Publications.

Manning, C. D., \& Schutze, H. (1999). Foundations of statistical natural language processing. MIT Press.

McCarthy, M., O’Keeffe, A., \& Walsh, S. (2010). Vocabulary matrix - Understanding, learning, teaching. Cengage Learning.

McLaughlin, B. (1990). Restructuring. Applied Linguistics, 11, 113-128.

Meara, P. (1980). Vocabulary acquisition: A neglected aspect of language learning. Language Teaching and Linguistics 13, 221-245. https://doi.org/10.1017/S0261444800008879

Miller, G. A. (1956). The magical number seven, plus or minus two: Some limits on our capacity for processing information. Psychological Review, 63, 81-97.

Minda, M. (2003). The effectiveness of current vocabulary teaching techniques in facilitating production in junior secondary schools: Grade seven in focus [Unpublished master dissertation]. Addis Ababa University.

Moeller, A. J., Ketsman, O., \& Masmaliyeva, L. (2009). The essentials of vocabulary teaching: From theory to practice. Central States Conference on the Teaching of Foreign Languages.

Nation, I. S. P. (1990). Teaching and learning vocabulary. Newbury House.

Nation, I. S. P. (1991). Dictation, dicto-comp and related techniques. English Teaching 
Nation, I. S. P. (2001). Learning vocabulary in another language. Cambridge University Press.

Nation, I. S. P. (2005). Teaching vocabulary. Asian EFL Journal, 7(3), 47-54.

Nattinger, J., \& DeCarrico, J. (1992). Lexical phrases in language teaching. Oxford University Press.

Newell, A., \& Rosenbloom, P. S. (1981). Mechanisms of skill acquisition and the law of practice. In J. R. Anderson (Ed.), Cognitive skills and their acquisition (pp. 1-53). Erlbaum.

Newell, A. (1990). Unified theories of cognition. The William James Lectures.

Ördem, E., \& Paker, T. (2016). Retention and use of lexical collocations (verb + noun and adjective + noun) by applying lexical approach in a reading course. European Journal Foreign Language Teaching, 1(1), 144-160.

Qader, H. B. A. (2016). The effect of lexical chunks on Kurdish EFL learners' writing skill. Education, 6(4), 101-106.

Rahimi, M., \& Momeni, G. (2012). The effect of teaching collocations on English language proficiency. Social and Behavioral Sciences 31, 37-42.

Rahimkhani, M., \& Hemmati, F. (2016). The impact of message units as 'chunks' on EFL production. Social Sciences \& Humanities, 24(4), 1503-1522.

Reza, K., \& Ashouri, S. (2016). The effect of lexical collocation instruction on intermediate EFL learners' vocabulary size. Indian Journal of Fundamental and Applied Life Sciences, 6(1), 416-425.

Richards, J. C., \& Rodgers, T. S. (2001). Approaches and methods in language teaching (2 ${ }^{\text {nd }}$ ed.). Cambridge University Press.

Richards, J. C., \& Renandya, W. A. (2002). Methodology in language teaching: An anthology of current practice. Cambridge University Press.

Richards, J. C. (2006). Communicative language teaching today. Cambridge University Press.

Rosenbloom, P. S., \& Newell, A. (1987). An integrated computational model of stimulus-response compatibility and practice. In J. H. Bower (Ed.), The psychology of learning and motivation: Advances in theory and research (vol. 21) (pp. 1989). Academic Press.

Sahragard, R., \& Sadighi, S. (2013). The effect of lexical collocational density on the Iranian EFL learners' reading comprehension. The Journal of Teaching Language Skills, 5(1), 111-136.

Schmidt, R. W. (1992). Psychological mechanisms underlying second language fluency. Studies in Second Language Acquisition, 14, 357-385.

Schmitt, N. (2004). Formulaic sequences: Acquisition, processing and use. John Benjamins Publishing Company.

Scrivener, T. (2011). Learning teaching: The essential guide to language teaching (2nd ed.). Macmillan.

Selivan, L. (2018). Lexical Grammar: Activities for Teaching Chunks and Exploring Patterns. Cambridge University Press.

Seyedrezaei, S. H., \& Ghezelseflou, M. (2015). The effect of teaching vocabulary through collocations on the vocabulary learning of Iranian EFL students. Journal of Language Sciences \& Linguistics, 3(1), 9-16. 
Shooshtari, Z. G., \& Karami, N. (2013). Lexical collocation instruction and its impact on Iranian non-academic EFL learners' speaking ability. Journal of Language Teaching and Research, 4(4), 767-776.

Sinclair, J. (1987). Looking up: An Account of the COBUILD Project in Lexical Computing and the Development of the Collins COBUILD English Language Dictionary. Collins ELT.

Singleton, D. (2000). Language and the lexicon: An introduction. Oxford University Press.

Tang, J. (2012). An empirical study on the effectiveness of the lexical approach to improving writing in SLA. Journal of Language Teaching and Research, 3(3), 578-583.

Tang, J. (2013). Input of chunks and its effects on L2 learners' listening competency. Theory and Practice in Language Studies, 3(7), 1264-1269.

Thornbury, S. (1998). The lexical approach: A journey without maps? MET, 7(4), 7-13.

Thornburry, S. (2002). How to teach vocabulary. Longman.

Timmis, I. (2008). The Lexical Approach is dead: Long live the lexical dimension! Modern English Teacher 7(3). http:/ /www.onlinemet.com/

Tremblay, A., Derwing, B., Libben, G., \& Westbury, C. (2011). Processing advantages of lexical bundles: Evidence from self-paced reading and sentence recall tasks. Language Learning 61, 569-613.

Tuan, N. H., \& Nguyen, N. B. (2014). The use of lexical approach in enhancing learners' oral communication performance at Nguyen Hue University. Journal of Science Ho Cbi Minh City Open University, 2(10), 72-80.

Westfall, T., \& Weber, C. (2005). English to go: Lexical approach methodology. https://www.oebv. at/system/files/celum/371891_developing_sense.pdf

Willis, D. (1990). The lexical syllabus. Harper Collins.

Willis, D. (2003). Rules, patterns and words: Grammar and lexis in English language teaching. Cambridge University Press.

Wray, A. (2000). Formulaic sequences in second language teaching: Principle and practice. Applied Linguistic, 21(4), 463-489.

Xu, R., Mao, Z., \& Liu, Y. (2012). Lexical approach and its application in college English classes. Theory and Practice in Language Studies, 2(10), 2090-2095.

Yu, X. (2013). From memorized chunks to rule formation: A study of adult Chinese learners of English. International Journal of Applied Linguistics \& English Literature, 2(1), 98-111. http://dx.doi.org/10.7575/ijalel.v.2n.1p.98

Zafarghandi, A. M., Tahriri, A., \& Bandari, M. D. (2015). The impact of teaching chunks on speaking fluency of Iranian EFL learners. Iranian Journal of English for Academic Purposes, 1(4), 36-47. 